\title{
EFFECTS OF FOOD NUTRIENT CONTENT, INSECT AGE AND STAGE IN THE FEEDING CYCLE ON THE FMRFamide IMMUNOREACTIVITY OF DIFFUSE ENDOCRINE CELLS IN THE LOCUST GUT
}

\author{
ENRIQUE ZUDAIRE ${ }^{1}$, STEVE J. SIMPSON ${ }^{2}$ AND LUIS M. MONTUENGA ${ }^{1, *}$ \\ ${ }^{1}$ Department of Histology and Pathology, Faculty of Medicine, University of Navarra, E-31080 Pamplona, Spain and \\ ${ }^{2}$ Department of Zoology and University Museum of Natural History, University of Oxford, South Parks Road, Oxford \\ OX1 3PS, UK \\ *e-mail: 1montuenga@unav.es
}

Accepted 12 August; published on WWW 8 October 1998

\begin{abstract}
Summary
We have studied the influence of variations in dietary protein and digestible carbohydrate content, of insect age and of time during the feeding cycle on the endocrine cells of the ampullar region of the midgut in the African migratory locust Locusta migratoria L. Morphometric analysis of FMRFamide-like immunoreactivity was used as an indirect measure of the amount of FMRFamide-related peptides (FaRPs) stored in the gut endocrine cells. There was a highly significant correlation between FaRP content and the nutritional quality of the food, measured relative to the concentrations and ratio of protein to digestible carbohydrate in a nutritionally optimal diet. The direction of the relationship between FaRP content and diet quality varied with age during the fifth stadium. On day 1 , FaRP levels increased with the nutritional quality of the food, while on day 4 the opposite relationship was observed. Release of peptide was triggered by the onset of a meal during ad libitum feeding, with cell FaRP levels returning to premeal values within $15 \mathrm{~min}$ of the meal ending. The

results also suggested that cell contents were released during food deprivation beyond the normal intermeal interval. Locusts switched for a single meal during ad libitum feeding on day 4 from a low- to a high-carbohydrate food did not respond by reducing endocrine cell FaRP content. Our results show a relationship between the diffuse gut endocrine system and feeding and nutrition in locusts. The ampullar endocrine cells are in three-way contact with the midgut luminal contents, with the primary urine from the Malpighian tubules and with the haemolymph. They are thus ideally positioned to play an integrative receptor-secretory function in the regulation of a variety of post-ingestive processes, such as enzyme secretion, absorption, gut motility or nutrient metabolism.

Key words: endocrine cell, FMRFamide, protein, carbohydrate, Locusta migratoria, midgut, feeding, behaviour, diet, nutritional balance.
\end{abstract}

\section{Introduction}

Herbivorous insects, like many other animals, are able to compensate both behaviourally and physiologically for nutritional discrepancies to obtain an optimal intake of energy and nutrients (Simpson and Simpson, 1990; Simpson and Raubenheimer, 1993a; Simpson et al. 1995; Raubenheimer and Simpson, 1997). A range of nutrient-specific and more general mechanisms has been shown to underlie these responses, particularly in the African migratory locust, with the haemolymph playing an important role as the site of integration between behavioural control and post-ingestive processing (Simpson and Raubenheimer, 1993b, 1996; Raubenheimer and Simpson, 1996).

In addition to regulating their intake of protein and carbohydrate by altering the amounts eaten and foods selected, locusts also differentially utilize these macronutrients, primarily it seems by excreting (in the case of protein nitrogen) or respiring (carbohydrate) nutrients ingested in excess of requirements (Zanotto et al. 1993, 1994, 1997). Compensatory modulation of the efficiencies of digestion or absorption from the gut do not seem to occur in the locust. Indeed, studies on locusts and other insects indicate a secretagogue mechanism for digestive enzyme secretion (Broadway and Duffey, 1986; Lehane et al. 1996), which would be expected to exacerbate, not to compensate for, food nutrient imbalances (Simpson $e t$ al. 1995).

The diffuse endocrine system of the gut is ideally positioned for involvement in the control of digestion, absorption and nutrient metabolism. It consists of a variety of endocrine cell types spread among the enterocytes of the locust midgut wall (Montuenga et al. 1989, 1994). These scattered cells occur more frequently in the posterior regions of the midgut and are particularly concentrated in the ampullae through which the 
Malpighian tubules drain into the enteric lumen at the junction between the mid and hindgut (Montuenga et al. 1985, 1994). The ampullae of the Malpighian tubules are a group of labyrinthine epithelial structures, located at the midgut-hindgut junction, that connect the Malpighian tubules to the gut. Histologically, they are similar in structure to the midgut wall, being composed of enterocytes and nidi of regenerative cells, interpersed with endocrine cells. In fact, the ampullae have recently been proposed as a new specialized endocrine organ in which the open-type endocrine cells are able to detect changes in the composition of the material present in the midgut or in the lumina of the Malpighian tubules (Montuenga et al. 1996). Very little is known about the role, if any, played in nutritional physiology by the diffuse endocrine system and its secretions. These secretions include FMRFamide-related peptides (FaRPs), which are released from the brain following feeding in Rhodnius prolixus (Elia et al. 1993). An involvement of FaRPs in digestive processes has been suggested for locusts and other insects (Evans and Myers, 1986; Robb and Evans, 1990; Fujisawa et al. 1993). A specific FMRFamide-secretagogue effect has been described in the scallop Pecten maximus (Favrel et al. 1994).

Our aim in the present work was to investigate whether the control of nutritional physiology involves the diffuse endocrine cell population of the locust midgut. We have exposed locusts to synthetic foods varying in protein and carbohydrate content at two ages during the fifth stadium and at various times throughout the feeding cycle and recorded the immunoreactivity of the endocrine cell population to FaRPs.

\section{Material and methods \\ Locusts and diets}

Experimental insects (some 250 Locusta migratoria L.) were reared at the Department of Zoology, Oxford University, using seedling wheat and wheat germ as a food source. Locusts weighing 400-580 mg for males and 480-660 $\mathrm{mg}$ for females were collected within $4 \mathrm{~h}$ after ecdysing to the fifth stadium (termed day 0). Eight dry, granular synthetic foods were used across four experiments and contained the following percentages of protein to digestible carbohydrate: $7: 35,7: 21$, 14:28, 21:21, 7:7, 28:14, 21:7 and 35:7. Casein, peptone and albumen $(3: 1: 1)$ constituted the protein source, while sucrose and dextrin (1:1) provided digestible carbohydrate. Changes in the levels of these nutrients were compensated for by altering the amount of indigestible cellulose added, while all other nutrients were present at the same level (4\%). Further details of the foods can be found in Simpson and Abisgold (1985).

\section{Experimental procedure}

Locusts were housed individually in clear plastic boxes $(17 \mathrm{~cm} \times 12 \mathrm{~cm} \times 6 \mathrm{~cm})$ containing an aluminium perch, a water dish and a Petri dish of food. They were kept at $30^{\circ} \mathrm{C}$ under a $12 \mathrm{~h}: 12 \mathrm{~h}$ L:D photoregime. Four experiments were performed.

(1) Thirty newly ecdysed fifth-instar nymphs (15 males, 15 females) were kept until day 4 on one of five synthetic foods: (\%protein:\%digestible carbohydrate, P:C) 7:35, 14:28, 21:21, 28:14 or 35:7. Nymphs were taken during the light phase of day 4 as they commenced a meal during ad libitum feeding (defined as having walked to the food dish and fed for $10 \mathrm{~s}$ ). After crushing the head capsule, the tip of the abdomen was removed and the head was pulled until the cervical membrane tore. Next, the entire gut was gently pulled out of the body by the head and opened along its length using bowspring scissors. The gut contents were removed, and the tissue was pinned flat onto a piece of photographic paper $(3 \mathrm{~cm} \times 1 \mathrm{~cm})$ in a wax dish. The dissected and pinned gut, with its paper support, was then placed into Bouin's fluid for $24 \mathrm{~h}$. Thereafter, the fixed guts were removed from the photographic paper and washed and stored in $70 \%$ ethanol prior to embedding in paraffin wax.

(2) Twenty-four nymphs (12 males, 12 females) were fed one of four synthetic foods (P:C 7:7, 7:21, 21:7 or 21:21) and their guts were sampled (as described above) either on day 1 or day 4.

(3) The guts were removed from 36 nymphs (18 males, 18 females) kept until day 4 on food of P:C 21:21 and taken at one of the following times during ad libitum feeding: as a meal commenced, $1 \mathrm{~min}$ into the meal, at the end of the meal (defined as a period of $4 \mathrm{~min}$ without feeding following $1 \mathrm{~min}$ or more of continuous ingestion) and 15,30 or $60 \mathrm{~min}$ after the meal ended.

(4) Eighteen nymphs (nine males, nine females) were fed until day 4 on a diet of either P:C 21:7 or 21:21 and then provided for a single meal during ad libitum feeding with either the same food or the other food. Insects given 21:7 after 21:21 invariably rejected the new low-carbohydrate food, so no data were forthcoming from that treatment. Guts were dissected, fixed and embedded as described above.

\section{Immunocytochemistry}

For the immunocytochemical localization of FMRFamidelike epitopes in paraffin wax sections ( $3 \mu \mathrm{m}$ in thickness), a variant of the avidin-biotin complex (ABC) technique of Hsu et al. (1981) was employed. After removal of paraffin wax with xylol, followed by $10 \mathrm{~min}$ in absolute ethanol, endogenous peroxidase was blocked by treatment with $3 \% \mathrm{H}_{2} \mathrm{O}_{2}$ in absolute methanol. Sections were then hydrated through a graded series of ethanol $(96 \%, 80 \%, 70 \%)$ and rinsed for $5 \mathrm{~min}$ in deionized water to remove any remaining alcohol. Slides were rinsed in deionized water and then placed in Tris/HCl-buffered saline (TBS: $0.05 \mathrm{moll}^{-1}$ Tris buffer, $\mathrm{pH} 7.4$, and $0.5 \mathrm{moll}^{-1} \mathrm{NaCl}$ ). Non-specific binding sites were blocked with $5 \%$ rabbit normal serum in TBS, and the sections were incubated overnight at $4{ }^{\circ} \mathrm{C}$ with anti-FMRFamide serum (rabbit anti-FMRFamide immunoglobulins; DAKO, Barcelona, Spain) diluted in TBS. Several dilutions of the primary antiserum were tested (from $1: 100$ to $1: 40000)$ to obtain optimal immunolabelling, according to the requirements for the subsequent image analysis quantification (McBride, 1996). A final 1:2000 dilution of the serum was used in all experiments. Following treatment with the primary antiserum, sections were rinsed in TBS ( $5 \mathrm{~min}$ ) and then incubated for $30 \mathrm{~min}$ at room temperature $\left(20-22^{\circ} \mathrm{C}\right)$ with 
biotinylated pig anti-rabbit antiserum (DAKO, Barcelona, Spain) diluted 1:200 in TBS. After a second rinse in TBS, the sections were treated for $30 \mathrm{~min}$ at room temperature with an avidin-biotin-peroxidase complex (DAKO, Barcelona, Spain) diluted 1:100 in TBS prepared $30 \mathrm{~min}$ in advance. The sections were washed in TBS and then in acetate buffer $\left(0.1 \mathrm{moll}^{-1}\right.$ acetic acid, $\mathrm{pH} 6$ ). Peroxidase activity was demonstrated by the diaminobenzidine (DAB) $/ \mathrm{H}_{2} \mathrm{O}_{2}$ method (Sigma Chemical Company, Madrid, Spain). The reaction was intensified with nickel according to Shu and Fan (1988). The solution was prepared by mixing a solution of $50 \mathrm{mg}$ of DAB in $50 \mathrm{ml}$ of deionized water with a second solution made up by adding $2.5 \mathrm{~g}$ of ammonium nickel sulphate [di-ammonium nickel(II) sulphate 6-hydrate; BDH Laboratory Supplies, UK], $200 \mathrm{mg}$ of $\beta$-D(+)-glucose (Sigma Chemical Co., Madrid, Spain), $40 \mathrm{mg}$ of ammonium chloride (Sigma Chemical Co., Madrid, Spain) and $30 \mathrm{mg}$ of glucose oxidase (Sigma Chemical Co., Madrid, Spain) in $50 \mathrm{ml}$ of acetate buffer. Finally, the sections were washed in distilled water, lightly counterstained with haematoxylin, dehydrated and mounted in DPX for microscopy. Experimental conditions for the immunolabelling, including batches of reagents and the time of DAB development, were kept constant across all experiments. Negative controls (omission of all stages of the immunocytochemical protocol, the use of non-immune rabbit serum at the first stage and preabsorption of the antiserum with FMRFamide) were performed and gave no immunocytochemical reaction.

\section{Quantification of the immunocytochemical reaction}

The immunocytochemical reaction was quantified using the
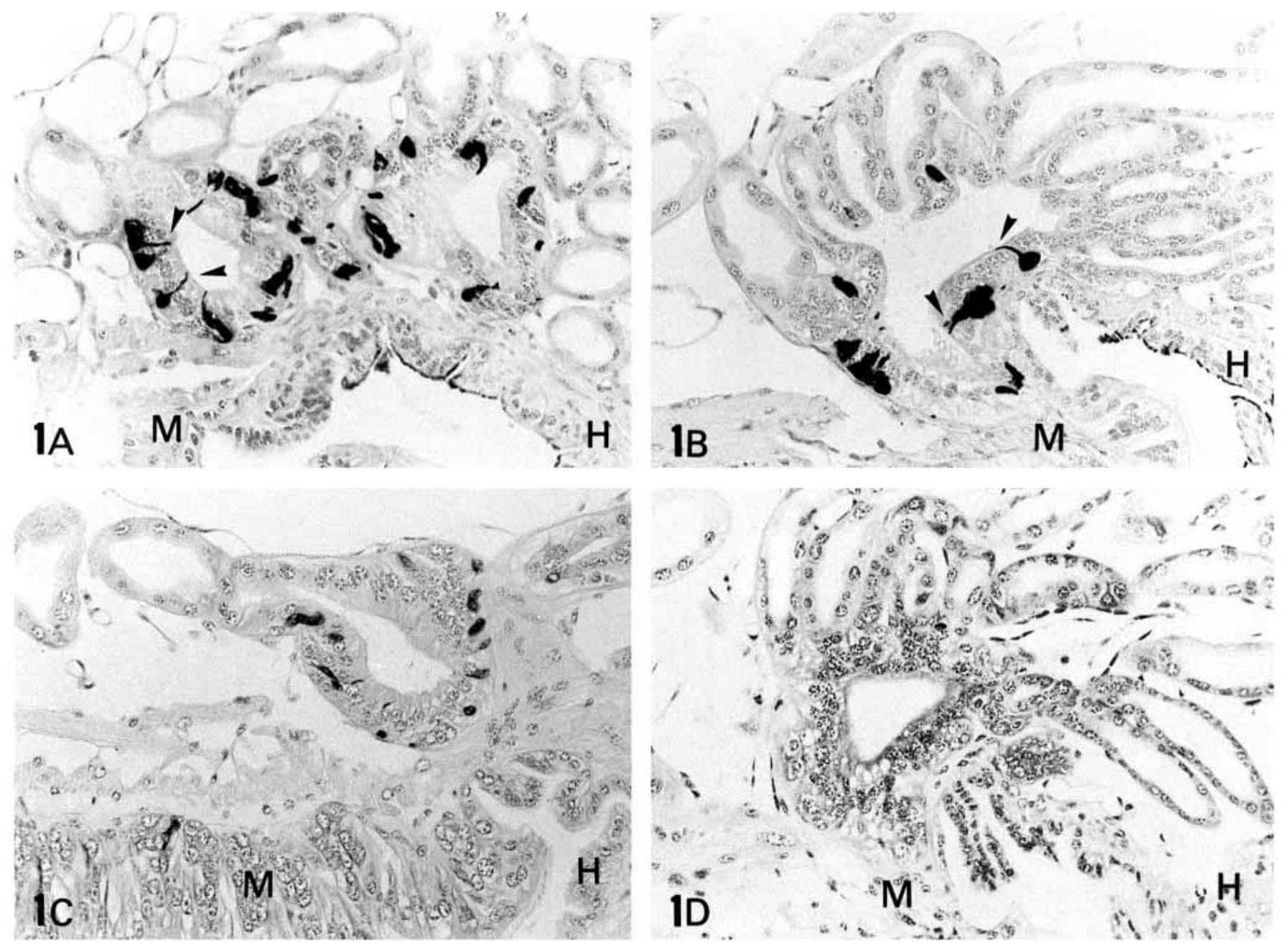

Fig. 1. Paraffin wax sections of ampullae of the Malpighian tubules from day 4, fifth-instar locust nymphs, showing FMRFamide-like immunoreactive endocrine cells. (A) Ampulla from an insect fed the nutritionally unbalanced diet 35:7 (\% protein:\% carbohydrate). The endocrine cells show high levels of darkly staining immunoreactive material in their cytoplasm. (B) Section of an ampulla from a 7:35-fed locust, also showing high levels of FMRFamide-like immunoreactive material in the endocrine cells. (C) Section from a locust fed diet 21:21, which is close to being nutritionally balanced. The endocrine cells contain less immunoreactive material and thus the EPA values are lower. (D) An adjacent serial section to B incubated with antibody preabsorbed with FRMFamide as a control. This preabsorption control shows no staining for FMRFamide. Arrowheads in A and B indicate endocrine cells showing slender cytoplasmic processes that reach the lumen. M, midgut epithelium; $\mathrm{H}$, hindgut epithelium. $\times 100$. 
image analyzer Visilog 4. Four sections of the gut from each experimental insect were randomly selected from 50 serial sections. All the ampullae present in each of the selected slides were measured. The image analysis program was adapted to quantify the relative immunoreactive area of the endocrine cells compared with the area of non-endocrine ampullar cells. A threshold was set to detect only the immunoreactive material but not the background. The ratio between the stained (endocrine) area and the total (endocrine + non-endocrine) area of the ampullae in each section was used as an indirect value to assess the relative amount of antigen present, using the following calculation:

$$
\mathrm{EPA}=(\text { immunostained area/total area }) \times 100,
$$

where EPA is the endocrine percentage area, the immunostained area is the value of immunostained area corresponding to all the endocrine cells visible in all the ampullae of a given section, and the total area is the sum of the immunostained and non-immunostained areas within the same ampullae.

\section{Statistical analyses}

Analysis of variance (ANOVA), Student's $t$-test, linear regression and analysis of covariance (ANCOVA) were used on arcsine-transformed EPA data.

\section{Results}

A large number of endocrine FMRFamide-like immunoreactive (FMRFa-IR) cells were readily observed in the ampullae of the Malpighian tubules using the immunocytochemical technique (Fig. 1). They were usually elongated or bottle-shaped and showed a slender cytoplasmic process through which they reached the ampullar lumen. Although our quantitative study was restricted to the ampullae of the Malpighian tubules, the technique also showed an abundance of FMRFa-IR cells throughout the midgut, especially in the posterior region. Negative controls performed as described above supported the specificity of our immunoreaction: staining was abolished when the FMRFamide antiserum was preabsorbed with FMRFamide (Fig. 1D).

\section{Effect of nutrient content of food on day 4 EPA values}

When insects in the first experiment were sampled at the beginning of a meal during ad libitum feeding on day 4, profound differences were apparent in ampulla EPA with nutritional quality of the food $(P<0.00001$ for the effect of diet in an ANOVA; $F=13.03$; d.f.=4,32; Fig. 2). In some cases, these differences were evident by direct observation under the microscope without the aid of image analysis (Fig. 1A-C). Values were lowest for diet 21:21, which is known from earlier work to be close to the optimal ratio and concentration of protein and carbohydrate for fifth-instar locusts (P:C 18:23) (Simpson and Raubenheimer, 1993a; Chambers et al. 1995; Raubenheimer and Simpson, 1997). As the diets became increasingly unbalanced with respect to their ratio of protein to carbohydrate, EPA rose (Fig. 2).

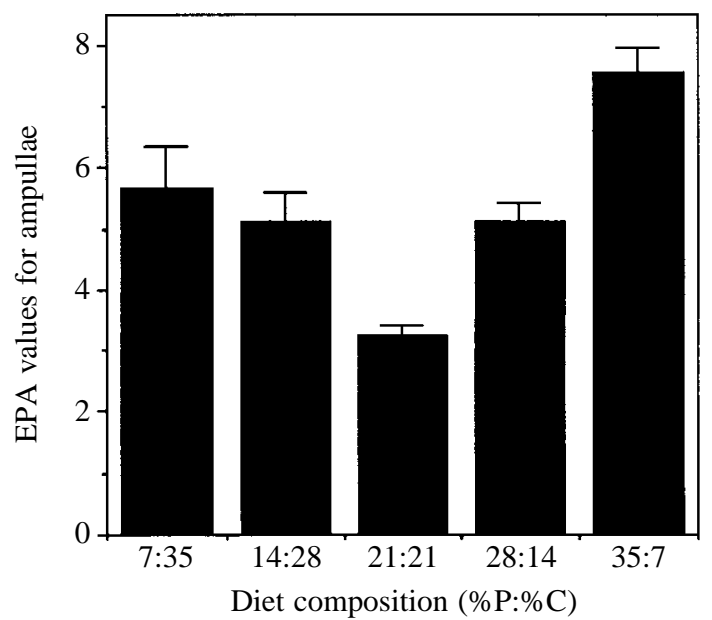

Fig. 2. Mean (+ S.E.M., $N=6$ ) endocrine percentage area (EPA) values in the ampullae of day 4, fifth-instar locusts fed one of five artificial diets varying in the levels of proteins $(\mathrm{P})$ and digestible carbohydrate (C) (P:C, 7:35, 14:28, 21:21, 28:14 and 35:7; see Materials and methods). Note that, as diets became increasingly unbalanced, EPA values rose significantly $(P<0.00001$; ANOVA). Diet 21:21 is close to being nutritionally balanced for locust nymphs with respect to protein and carbohydrate (Chambers et al. 1995).

Hence, these results indicate that EPA is somehow related to the nutritional balance of a locust's diet. In the experiment shown in Fig. 2, the total concentration of protein and digestible carbohydrate was kept constant at $42 \%$ dry mass of the food, and so the experiment tested the effect of the ratio of protein:carbohydrate in the diet as well as the possible effects of the concentration of one or other nutrient group. If the ratio of the two macronutrients were exerting the major effect, then it might be expected that food containing $7 \%$ protein and $7 \%$ carbohydrate, which is close to an optimally balanced P:C ratio, but is nutritionally dilute, would, like food $21: 21$, provide low values for EPA. Alternatively, if the overall nutritional quality of the diet, not just the ratio of protein to carbohydrate but also their amounts, is the key variable, then 7:7 should induce elevated levels of EPA relative to 21:21. In fact, EPA values on day 4 were significantly higher in insects fed 7:7 than in those fed 21:21 $(P<0.005)$ (Fig. 3B). Also consistent with this result were EPA values from nymphs fed $21: 7$ or $7: 21$, both of which were elevated relative to those of locusts fed 21:21, with the effect being more marked for 21:7 $(P<0.005$ in both cases) (Fig. 3B).

To explore further the hypothesis that the nutritional value of the food, with respect both to the ratio and to the concentration of protein and carbohydrate, influenced values for EPA, data from experiments 1, 2 and 4 (the unchanged treatments of the latter) were combined and regressed against a geometric measure of diet quality, namely the distance in percentage nutrient space of each of the eight experimental foods from what is known to be the optimal diet composition of 18:23 (Chambers et al. 1995) (see Fig. 4 and its legend for a description of the method and rationale). The regression was positive and highly 
significant $\left(F=56.0\right.$, d.f. $\left.=1,78 ; P<0.00001 ; r^{2}=0.418\right)$. When sex and experiment number were included as factors in an ANCOVA with diet distance as the covariate, the covariate explained virtually all the variance, leaving no effect attributable to sex $(F=0.46 ;$ d.f. $=1,76 ; P=0.499)$, experiment $(F=0.001$; d.f. $=2,76 ; P=0.996)$ or their interaction $(F=0.05$, d.f. $=2,76$; $P=0.950$ ). These results are summarized in Fig. 5B. In short, EPA values were strongly correlated with the nutritional quality of the food, rising as either the protein:carbohydrate ratio or the overall concentrations of protein and carbohydrate shifted away from a previously determined optimal diet composition.

\section{Changes with insect age: days 1 and 4 compared}

When locusts were fed diets 7:21, 7:7, 21:21 or 21:7 and their guts were sampled either on day 1 or on day 4 , there was a complete shift in the relationship between EPA values and diet over this period. Whereas on day 4 there was a strong positive relationship between EPA and the distance of the diet

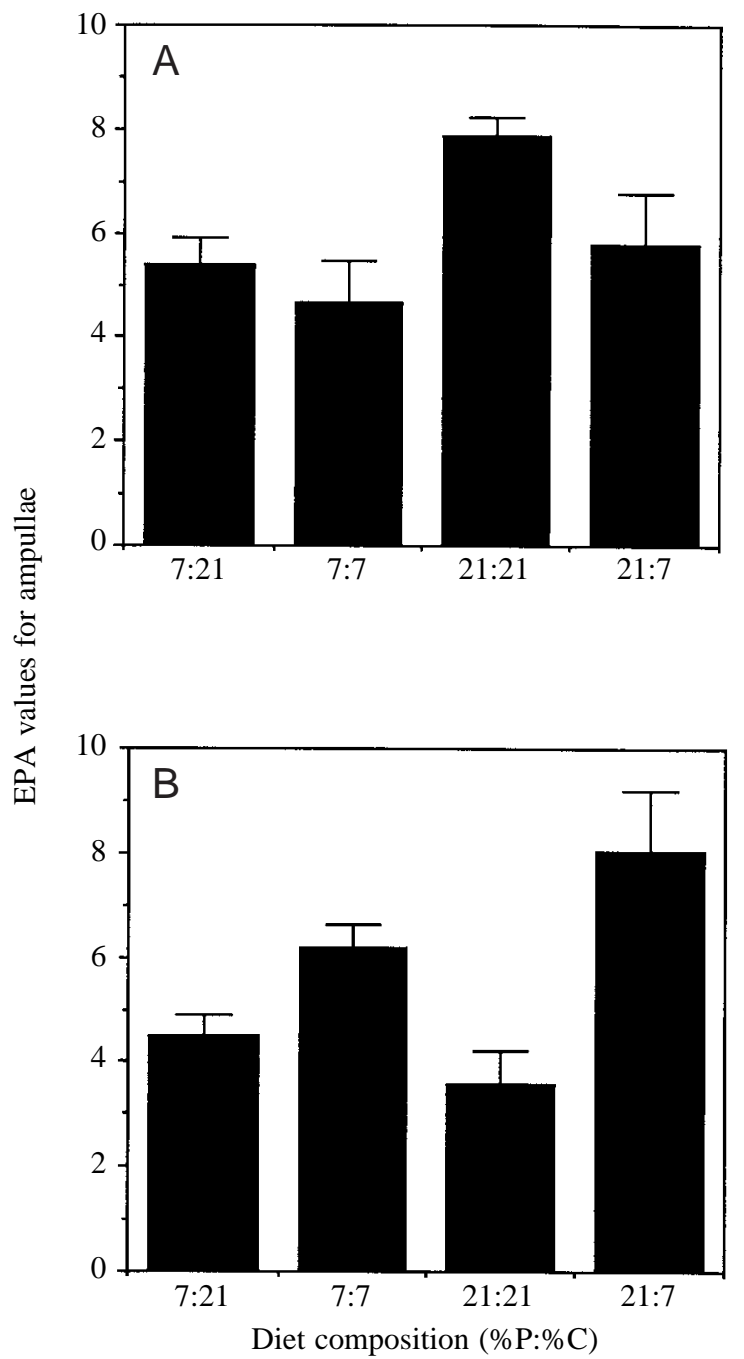

Fig. 3. Mean (+ S.E.M., $N=6$ ) endocrine percentage area (EPA) values for fifth-instar locusts fed one of four diets varying in protein $(\mathrm{P})$ and carbohydrate (C) content (P:C, 7:21, 7:7, 21:21 and 21:7) and sampled either on day 1 (A) or on day 4 (B) of the stadium. from the optimal in nutrient space, the relationship was highly significantly negative on day 1 (Fig. $5 \mathrm{~A} ; F=8.60$; d.f. $=1,20$; $P=0.0082$ ). As a result, an ANOVA with diet and day as factors showed a highly significant interaction between these two (compare Fig. 3A with Fig. 3B; $F=7.8$; d.f. $=3,33 ; P<0.0001$ ). Stadium duration averages 11-12 days for all diets except 7:35, where development is extended (to approximately 16 days) (Raubenheimer and Simpson, 1993). For all the diets tested, day 4 is a peak feeding day.

\section{Changes with time in the feeding cycle}

The EPA values for nymphs fed food 21:21 and sampled on day 4 varied significantly with time in the feeding cycle, being high at the start of feeding, falling rapidly during the meal $(t=2.61 ; P<0.05$ for start versus 1 min after groups; see Fig. 6$)$ and rising again thereafter $(t=-2.92 ; P<0.05$ for end of meal versus 15 min after groups; see Fig. 6). Values had attained premeal levels by $15 \mathrm{~min}$ after the meal ended, presumably reflecting recovery of the peptide contents either by resynthesis or by stimulation of postranslational processes following feeding-induced peptide release, but thereafter fell somewhat, although not significantly $(t=0.81 ; P=0.43$ for $15 \mathrm{~min}$ after

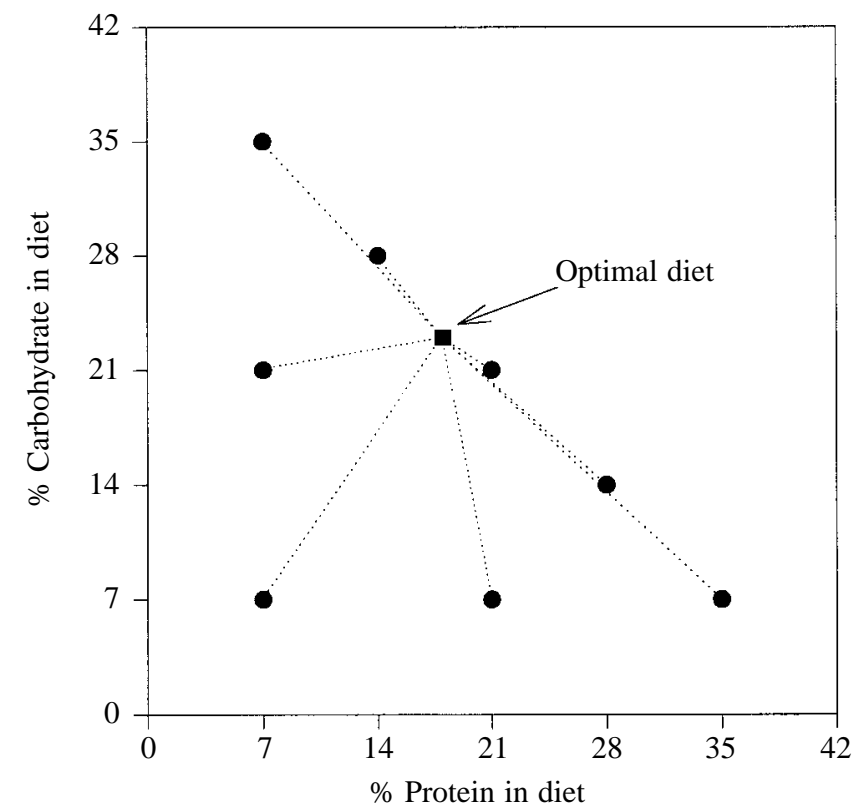

Fig. 4. Nutritional plane for percentage dietary protein $(\mathrm{P})$ and digestible carbohydrate $(C)$ showing the distance of each of the experimental diets from the composition of an optimal diet, the position of which (P:C, 18:23) is known from previous work (Chambers et al. 1995). The distance from the optimal diet is simply the Euclidean distance in percentage units between a given food and the optimal diet composition (calculated as the hypotenuse of the triangle with the percentage differences between the protein and digestible carbohydrate content of a food and the optimal diet as the other two sides). Extensive earlier work on the control of nutrient intake and locust performance on different diets has shown that this distance provides a direct measure of the nutritional quality of a food (see, for example, Simpson and Raubenheimer, 1993a, 1996; Raubenheimer and Simpson, 1997). 

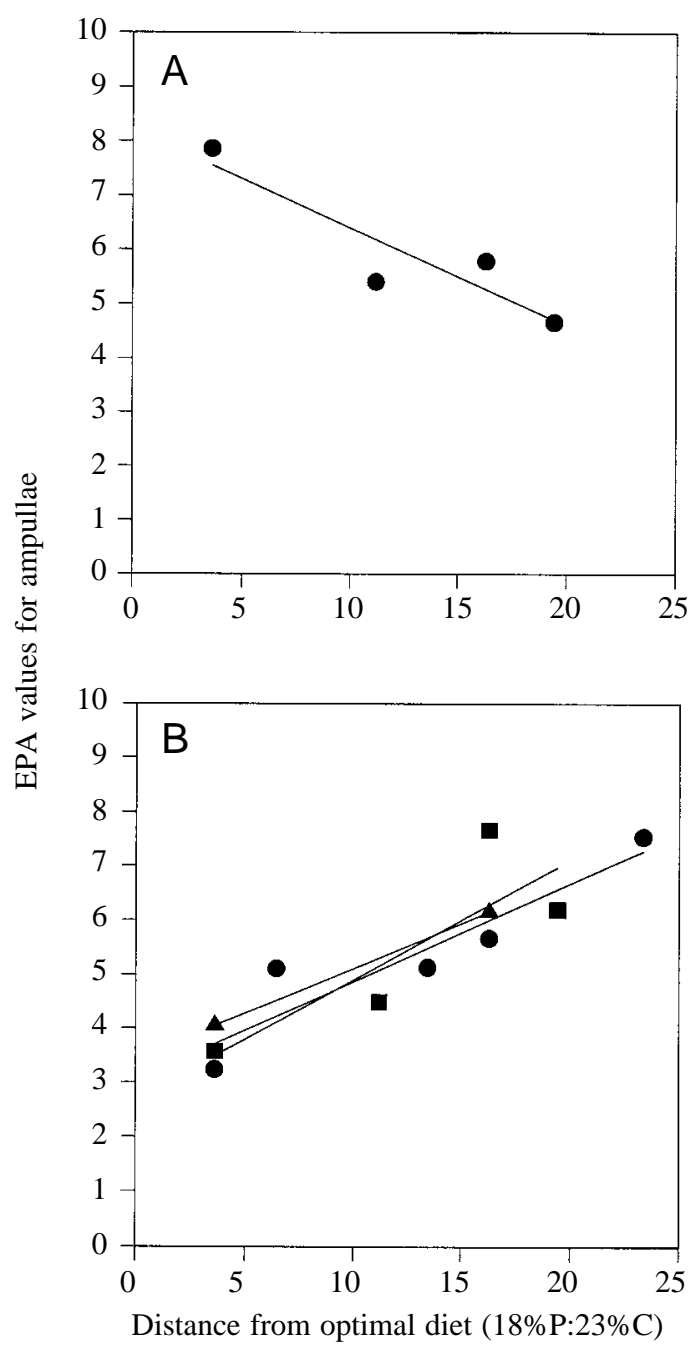

Fig. 5. The relationship between mean endocrine percentage area (EPA) values in locusts fed a given diet and the distance of this diet from a nutritionally optimal composition (see Fig. 4). Regression lines were fitted independently to data from three experiments. (A) The relationship on day 1 of the fifth stadium (data taken from experiment 2). (B) The relationship on day 4 . Here, data were taken from three experiments: experiments 1 (circles), 2 (squares) and 4 (triangles) (the data from experiment 4 correspond only to the insects whose foods were not changed during the test meal). Regression lines fitted to the raw data are shown.

versus 30 min after groups; see Fig. 6). This fall may have been related to the fact that locusts were kept without food while awaiting sampling at the preassigned interval after feeding. Given that an increasing proportion of insects would have fed again by 30 and $60 \mathrm{~min}$ had food been available (the mean intermeal interval for diet $21: 21$ is approximately $70 \mathrm{~min}$; Zanotto et al. 1996), this may indicate release of endocrine cell contents in response to food deprivation.

\section{Response to switching diet}

To determine whether EPA levels responded rapidly to changes in the nutritional quality of the diet, locusts were fed

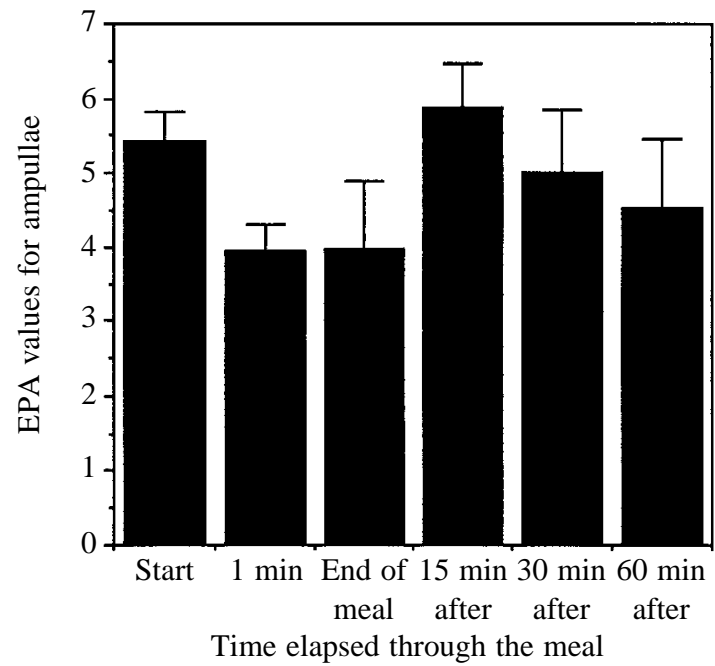

Fig. 6. Plot showing mean (+ S.E.M., $N=6$ ) endocrine percentage area (EPA) values for locusts fed on diet 21:21 (P:C) at different times in the ad libitum feeding cycle. EPA values fell during the meal and rose again $15 \mathrm{~min}$ after the meal ended. EPA values also dropped with further food deprivation (30-60 min).

for the first 4 days of the fifth stadium on either diet 21:7 or $21: 21$, then provided for a single meal during ad libitum feeding with either the same or the other food. Insects given 21:7 after 21:21 always rejected the new, less-balanced food, and so were omitted from analysis, while locusts switched to 21:21 after 21:7 took a meal of more than twice the duration of those kept on the same food. When locusts were sampled $30 \mathrm{~min}$ after the test meal, EPA values were significantly higher for insects pretreated on 21:7 than on 21:21, irrespective of whether they had fed for the test meal on 21:21 or 21:7 (Fig. 7; for the diet effect, $F=6.82$; d.f. $=2,29 ; P=0.004)$. There was no effect of meal duration as a covariate $(F=0.42$; d.f. $=2,29 ; P=0.524)$.

\section{Discussion}

The present results indicate that the diffuse endocrine system, in particular the FaRP-producing cells of the ampullae, are associated with the nutritional physiology of Locusta migratoria. The percentage area of ampulla epithelium exhibiting immunoreactivity to FaRPs (EPA) varied with the nutritional quality of the diet, with age during the stadium and with time during the feeding cycle. The EPA values reflect several processes, including rates of peptide synthesis and release, and of cell death, differentiation and proliferation. The experiment in which insects were sampled at different times during the feeding cycle provided evidence for a rapid release of peptide induced by the onset of feeding and of resynthesis of the peptide during the first $15 \mathrm{~min}$ of the following intermeal interval. The time course was too rapid for these results to be explained in terms of cell death or proliferation. Jenkins et al. (1989) have also shown in Heliothis zea larvae that food intake induces a quick release of FaRPs.

Changes produced within a longer time frame could be 


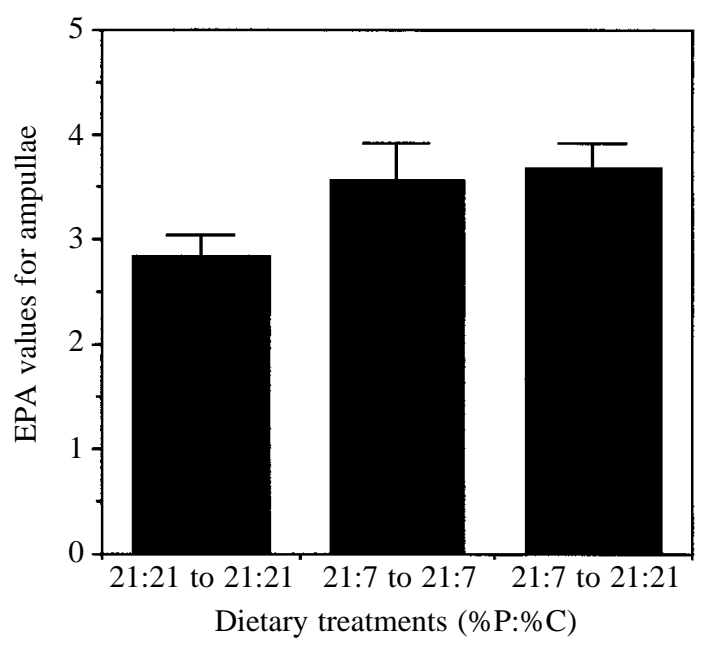

Fig. 7. Mean (+ S.E.M., $N=6)$ endocrine percentage area (EPA) values for locusts fed from the beginning of the fifth stadium until day 4 on diet 21:21 or 21:7 (P:C), then either fed on the same food or switched to the other food for a single meal during ad libitum feeding. Insects fed 21:7 after 21:21 did not feed.

mediated not only by variation in the intracellular levels of peptide but also by an induction of endocrine cell differentiation or proliferation by diet composition. Such an effect might explain the marked change seen from the beginning of the stadium (day 1), where EPA values rose with increasing nutritional quality of the food (as measured by the difference in protein and carbohydrate content of a food from the optimal diet composition) to day 4 where the reverse was the case. The pattern on day 1 could reflect a secretagogue response to dietary quality, with cells showing high levels of FaRP secretion in direct response to the nutritional quality of the food, monitored either by the endocrine cells themselves or elsewhere. However, with continued restriction to a suboptimal diet, the pattern is reversed as part of a compensatory response involving increased numbers of endocrine cells, thus retaining limiting nutrients or using them more efficiently. This would also explain why locusts switched for one meal from 21:7 to 21:21 did not immediately respond with reduced EPA values. Certainly, the pattern of feeding behaviour follows a similar time course pattern in the locust. More-nutritional foods, being the most phagostimulatory, are initially eaten in greatest quantities, but, with time, nutritional feedback induces compensatory feeding responses which result, for example, in more being eaten of nutritionally dilute foods (for a detailed discussion and mathematical model, see Simpson and Raubenheimer, 1996). Some earlier reports (Marion et al. 1983) have shown increased levels of thymidine uptake in the insect midgut depending on the composition of the diet. We are currently investigating the possible effect of diet on locust midgut cell proliferation.

In mammals, gut hormones play a role in the control of feeding and digestion (Forbes, 1992). For instance, cholecystokinin has been implicated in the control of satiety, both via a direct inhibition of feeding and by its effects on stomach emptying (Rayner, 1992; Gibbs, 1994). Likewise, pancreatic polypeptide is released by endocrine cells in the duodenum and pancreas and induces a dose-dependent inhibition of exocrine pancreatic secretion, the suppression of intestinal and gastric motility and a decrease in bile secretion (Hazelwood, 1993). Very little is known in invertebrates concerning the role of regulatory peptides in digestive processes, with the exception of the control of visceral muscle tone.

In recent years, FMRFamide has been the object of several investigations. This tetrapeptide was first described in the central nervous system of the crustacean Macrocallista nimbosa and was fully characterized by Price and Greenberg (1977). Since then, a number of different FaRPs have been demonstrated to be present not only in a variety of tissues in invertebrates (Price et al. 1990; Robb and Evans, 1990) but also in the brain and gut of vertebrates (Dockray et al. 1981; Gayton, 1982). FMRFamide seems to be involved in certain digestive processes in mammals, for example in the control of acid secretion in rats (Fehér and Burnstoc, 1989; Muthal and Chopde, 1993).

It is known in insects that the activity of visceral muscle is regulated by FaRPs (Peeff et al. 1993; Fujisawa et al. 1993). FMRFamide also modulates the response to 5hydroxytryptamine (5-HT) and proctolin in the foregut of Schistocerca gregaria (Banner and Osborne, 1989). Elia et al. (1993) showed an increase in FaRPs in haemolymph and a loss in neurohaemal areas following a meal in Rhodnius prolixus. Virtually nothing is known about the regulation by FaRPs of digestive processes other than gut motility in invertebrates. The only published data come from the scallop Pecten maximus, where a secretagogue effect of FMRFamide on amylase secretion was reported (Favrel et al. 1994).

The endocrine cells of the locust midgut have been the object of a small number of previous immunocytochemical studies, mainly using antibodies directed against mammalian peptides. These studies suggest the presence of a variety of regulatory peptides such as FMRFamide-, substance-P-, endothelin-1-, galanin-, bombesin- and peptide-YY-like peptides or Locusta diuretic hormone (Montuenga et al. 1989, 1996; Prado, 1993; Schoofs et al. 1993). Gut endocrine cells have been studied immunocytochemically in the cockroach Periplaneta americana (Iwanaga et al. 1981; Endo et al. 1982), and in a small number of other insect species, such as Aedes aegypti (Veenstra et al. 1995). As in mammals, the gut endocrine cells of insects are scattered between the enterocytes within the gut epithelium, constituting a true diffuse endocrine system (Montuenga et al. 1994). Co-localization studies have demonstrated that a number of FaRP-producing endocrine cells in the locust midgut also synthesize other peptides such as Locusta diuretic hormone (Montuenga et al. 1996). In the present study, endocrine cells were detected in the midgut ampullae of the locust by means of an immunocytochemical technique using an antibody against the sequence Phe-MetArg-Phe- $\mathrm{NH}_{2}$. It is well known that several FaRPs are present 
in different locust tissues (Robb and Evans, 1990), and a variety of these peptides are probably also produced by the endocrine cells of locust ampullae.

The results reported in the present paper support the hypothesis that the endocrine cells in the ampullae play a role in the control of digestive or other nutritional processes, but what that role is remains unclear. FMRFamide-like immunoreative cells are in direct contact with food in the gut lumen via a slender, apical cytoplasmic projection. They are also bathed by primary urine from the Malpighian tubules and their basal membranes are in contact with the haemolymph. The food, haemolymph and excreta are the three key compartments in the integration of nutritional homeostasis (Simpson and Raubenheimer, 1993b; Simpson et al. 1995). It is not inconceivable that the endocrine cells could serve as three-way difference detectors, in much the same way as mouthpart taste receptors act as comparators of haemolymph and food nutrient levels (Simpson and Simpson, 1992). Whatever their mode of action, it is clear that the diffuse endocrine cells in the ampullae of the Malpighian tubules of the locust provide an excellent model to investigate the release of bioactive peptides and their role in nutritional physiology.

We thank Ms Isabel Ordoqui and Mr Steve Roberts for their excellent technical assistance. This study was funded by Spanish grants from the Departamento de Educación del Gobierno de Navarra and the Spanish CICYT (PB 93-0711) and by the BBSRC in the UK.

\section{References}

BanNer, S. E. AND Osborne, R. H. (1989). Modulation of 5-HT and proctolin receptors by FMRFamide in the foregut of the locust Schistocerca gregaria. J. Insect Physiol. 35, 887-892.

Broadway, R. M. And Duffey, S. S. (1986). The effect of dietary protein on the growth and digestive physiology of larval Heliothis zea and Spodoptera exigua. J. Insect Physiol. 32, 673-680.

Chambers, P. G., Simpson, S. J. And Raubenheimer, D. (1995). Behavioural mechanisms of nutrient balancing in Locusta migratoria nymphs. Anim. Behav. 50, 1513-1523.

Dockray, G. J., Vaillant, C. and Williams, R. G. (1981). New vertebrate brain-gut peptide related to a molluscan neuropeptide and an opioid peptide. Nature 293, 656-657.

Elia, A. J., Tebrugge, V. A. And Orchard, I. (1993). The pulsatile appearance of FMRFamide-related peptides in the haemolymph and loss of FMRFamide-like immunoreactivity from neurohaemal areas of Rhodnius prolixus following a blood meal. J. Insect Physiol. 39, 459-469.

Endo, Y., Nishitssutsuj, U. J., Iwanaga, T. and Fujita, T. (1982). Ultrastructural and immunocytochemical identification of pancreatic polypeptide-immunoreactive cells in the cockroach midgut. Biomed. Res. 3, 454-456.

Evans, P. D. AND MYers, C. M. (1986). The modulatory actions of FMRFamide and related peptides on locust skeletal muscle. J. exp. Biol. 126, 403-422.

Favrel, P., Giard, W., Benlimane, N., Boucaud-Camou, E. And HENRY, M. (1994). A new biological activity for the neuropeptide
FMRFamide: experimental evidence for a secretagogue effect on amylase secretion in the scallop Pecten maximus. Experientia 50, 1106-1109.

FEHÉR, E. AND BuRnstock, G. (1989). Occurrence of FMFRamidelike immunoreactive nerve fibers in guinea pig small intestine. $J$. Histochem. Cytochem. 37, 1427-1433.

Forbes, J. M. (1992). Metabolic aspects of satiety. Proc. Nutr. Soc. 51, 13-19.

Fujisawa, Y., Shimoda, M., Kiguchi, K., IchiKawa, T. AND Fujita, N. (1993). The inhibitory effect of a neuropeptide, ManducaFLRFamide, on the midgut activity of the sphingid moth, Agrius convolvulis. Zool. Sci. 10, 773-777.

GAYTON, R. J. (1982). Mammalian neuronal actions of FMRFamide and related opioid Met-enkephalin-Arg ${ }^{6}-\mathrm{Phe}^{7}$. Nature 298, 275-276.

GiBBS, J. (1994). Gastrin-releasing peptide and satiety. Gastroenterol. 106, 1374-1387.

Hazelwood, R. L. (1993). The pancreatic polypeptide PP-family: gastrointestinal, vascular and feeding behavioral implications. Soc. exp. Biol. Med. 202, 44-63.

Hsu, S. M., RaIne, L. AND FAnger, H. (1981). Use of avidin-biotin-peroxidase complex $(\mathrm{ABC})$ in inmunoperoxidase techniques: a comparison between $\mathrm{ABC}$ and unlabeled antibody (PAP) procedures. J. Histochem. Cytochem. 29, 577-580.

Iwanaga, T., Fugita, T., Nishitsutsuji, U. J. And Endo, Y. (1981). Immunocytochemical demonstration of somatostatin-, enteroglucagon- and VIP-like immunoreactivities in the cockroach midgut. Biomed. Res. 2, 202-207.

Jenkins, A. C., Brown, M. R. AND CRIM, J. W. (1989). FMRF-amide immunoreactivity and the midgut of the Corn Earworm (Heliothis zea). J. exp. Zool. 252, 71-78.

Lehane, M. J., Muller, H. M. AND CRISANTI, A. (1996). Mechanisms controlling the synthesis and secretion of digestive enzymes in insects. In Biology of the Insect Midgut (ed. M. J. Lehane and P. F. Billingsley), pp. 195-205. London: Chapman \& Hall.

MARION, J. L., RichaRd, Y. S. AND MONIQUE, S. J. S. (1983). Influence of age and diet on DNA synthesis and the DNA content of mid-gut cells in the Dipteran Sarcophaga carnaria. Mec. Ageing Devl. 23, 37-52.

MCBRIDE, J. T. (1996). Quantitative immunocytochemistry. In Image Analysis in Histology, Conventional and Confocal Microscopy (ed. R. Wooton, D. R. Springall and J. M. Polak), pp. 339-354. Cambridge: Cambridge University Press.

Montuenga, L. M., Barrenechea, M. A., Sesma, P., Lopez, J. And VAZQUEZ, J. J. (1989). Ultrastructure and immunocytochemistry of endocrine cells in the midgut of the desert locust, Schistocerca gregaria (Forskal). Cell Tissue Res. 258, 577-583.

Montuenga, L. M., Prado, M. A., Springall, D. R., PolaK, J. M. AND SESMA, P. (1994). Endothelin-like immunoreactivity in midgut endocrine cells of the desert locust Locusta migratoria. Gen. comp. Endocr. 81, 433-441.

Montuenga, L., Villaro, C. A., Sesma, P. M. and Rada Diaz, O. (1985). Estudio histológico de los túbulos de Malpigio de Schistocerca gregaria (Forskal). II. Microscopía electrónica. Acta Microscópica 8, 195-212.

Montuenga, L. M., Zudaire, E., Prado, M. A., Audsley, N., Burrel, M. A. AND CoAst, G. M. (1996). Presence of Locusta diuretic hormone in endocrine cells of the ampullae of locust Malpighian tubules. Cell Tissue Res. 285, 331-339.

Muthal, A. V. AND Chopde, C. T. (1993). Stimulation of gastric acid 


\section{Effects of diet on locust endocrine cells 2979}

secretion by central administration of FMRFamide in rats. Indian J. med. Res. 98, 185-187.

Peeff, M. N., Orchard, I. And Lange, A. B. (1993). The effects of FMRFamide-related peptides on an insect (Locusta migratoria) visceral muscle. J. Insect Physiol. 39, 207-215.

Prado, M. A. (1993). Sistema neuroendocrino difuso y otras células secretoras de péptidos en los aparatos digestivo y excretor de Locusta migratoria: características inmunocitoquí micas y desarrollo en larvas y adultos. Doctoral thesis, University of Navarra, Pamplona, Spain.

Price, D. A. AND GreEnBerg, M. J. (1977). Structure of a molluscan cardioexcitatory neuropeptide. Science 197, 670-671.

Price, D. A., Lesser, W., LeE, T. D., Doble, K. E. AND Greenberg, M. J. (1990). Seven FMRFamide-related and two SCP-related cardioactive peptides from Helix. J. exp. Biol. 154, 412-437.

Raubenheimer, D. AND Simpson, S. J. (1993). The geometry of compensatory feeding in the locust. Anim. Behav. 45, 953-964.

Raubenheimer, D. And Simpson, S. J. (1996). Meeting nutrient requirements: the roles of power and efficiency. Ent. exp. Appl. 80, 65-68.

RAUBENHEIMER, D. AND Simpson, S. J. (1997). Integrative models of nutrient balancing: application to insects and vertebrates. Nutr. Res. Rev. 10, 151-179.

RAYNER, D. V. (1992). Gastrointestinal satiety in animals other than man. Proc. Nutr. Soc. 51, 1-6.

Robb, S. And Evans, D. P. (1990). FMRF-amide-like peptides in the locust: distribution, partial characterization and bioactivity. J. exp. Biol. 149, 335-360.

Schoofs, L., Vanderbroeck, K. And Deloof, A. (1993). The myotropic peptides of Locusta migratoria: Structures, distribution, function and receptors. Insect Biochem. molec. Biol. 23, 859-881.

SHU, S. J. G. AND FAN, L. (1988). The glucose oxidase-DAB-nickel method in peroxidase histochemistry of the nervous system. Neurosci. Lett. 85, 169-171.

Simpson, S. J. AND ABISGold, J. D. (1985). Compensation by locust for changes in dietary nutrients: behavioural mechanism. Physiol. Ent. 10, 443-452.

Simpson, S. J. AND RAUbENHEIMER, D. (1993a). A multi-level analysis of feeding behaviour: the geometry of nutritional decisions. Phil. Trans. $R$. Soc. Lond. B 342, 381-402.

Simpson, S. J. AND RAubenheimeR, D. (1993b). The central role of the haemolymph in the regulation of nutrient intake in insects. Physiol. Ent. 18, 395-403.

Simpson, S. J. AND RAUbenHeIMER, D. (1996). Feeding behaviour, sensory physiology and nutrient feedback: a unifying model. Ent. exp. Appl. 80, 55-64.

Simpson, S. J., Raubenheimer, D. And Chambers, P. G. (1995). Nutritional homeostasis. In Regulatory Mechanisms of Insect Feeding (ed. R. F. Chapman and G. de Boer), pp. 251-278. New York: Chapman \& Hall.

Simpson, S. J. AND Simpson, C. L. (1990). The mechanism of compensation by phytophagous insects. In Insect-Plant Interactions, vol. II (ed. E. A. Bernays), pp. 111-160. Boca Raton, FL: CRC Press.

Simpson, S. J. AND Simpson, C. L. (1992). Mechanism controlling modulation by haemolymph amino acids of gustatory responsiveness in the locust. J. exp. Biol. 168, 269-287.

Veenstra, J. A., Lau, G. W., Agricola, H. J. and Petzel, D. H. (1995). Immunohistological localization of regulatory peptides in the midgut of the female mosquito Aedes aegypti. Histochem. Cell Biol. 104, 337-347.

Zanotto, F. P., Gouveia, S. M., Simpson, S. J., Raubenheimer, D. AND CALDER, P. C. (1997). Nutritional homeostasis in locusts: is there are mechanism for increased energy expenditure during carbohydrate overfeeding? J. exp. Biol. 200, 2437-2448.

Zanotto, F. P., Raubenheimer, D. And Simpson, S. J. (1994). Selective egestion of lysine by locusts fed nutritionally unbalanced foods. J. Insect Physiol. 40, 259-265.

Zanotto, F. P., Raubenheimer, D. And Simpson, S. J. (1996). Haemolymph amino acid and sugar levels in locusts fed nutritionally unbalanced diets. J. comp. Physiol. B 166, 223-229.

Zanotto, F. P., Simpson, S. J. And Raubenheimer, D. (1993). The regulation of growth by locusts through post-ingestive compensation for variation in the levels of dietary protein and carbohydrate. Physiol. Ent. 18, 425-434. 